\title{
Front Matter: Volume 10988
}

, "Front Matter: Volume 10988," Proc. SPIE 10988, Automatic Target Recognition XXIX, 1098801 (22 July 2019); doi: 10.1117/12.2537890

SPIE Event: SPIE Defense + Commercial Sensing, 2019, Baltimore, MD, United SPIE. States 


\section{PROCEEDINGS OF SPIE}

\section{Automatic Target Recognition XXIX}

Riad I. Hammoud

Timothy L. Overman

Editors

15-18 April 2019

Baltimore, Maryland, United States

Sponsored by

SPIE

Cosponsored by

Lockheed Martin Corporation

Published by

SPIE 
The papers in this volume were part of the technical conference cited on the cover and title page. Papers were selected and subject to review by the editors and conference program committee. Some conference presentations may not be available for publication. Additional papers and presentation recordings may be available online in the SPIE Digital Library at SPIEDigitalLibrary.org.

The papers reflect the work and thoughts of the authors and are published herein as submitted. The publisher is not responsible for the validity of the information or for any outcomes resulting from reliance thereon.

Please use the following format to cite material from these proceedings:

Author(s), "Title of Paper," in Automatic Target Recognition XXIX, edited by Riad I. Hammoud, Timothy L. Overman, Proceedings of SPIE Vol. 10988 (SPIE, Bellingham, WA, 2019) Seven-digit Article CID Number.

ISSN: 0277-786X

ISSN: 1996-756X (electronic)

ISBN: 9781510626416

ISBN: 9781510626423 (electronic)

Published by

SPIE

P.O. Box 10, Bellingham, Washington 98227-0010 USA

Telephone +1 3606763290 (Pacific Time) · Fax +1 3606471445

SPIE.org

Copyright @ 2019, Society of Photo-Optical Instrumentation Engineers.

Copying of material in this book for internal or personal use, or for the internal or personal use of specific clients, beyond the fair use provisions granted by the U.S. Copyright Law is authorized by SPIE subject to payment of copying fees. The Transactional Reporting Service base fee for this volume is $\$ 18.00$ per article (or portion thereof), which should be paid directly to the Copyright Clearance Center (CCC), 222 Rosewood Drive, Danvers, MA 01923. Payment may also be made electronically through CCC Online at copyright.com. Other copying for republication, resale, advertising or promotion, or any form of systematic or multiple reproduction of any material in this book is prohibited except with permission in writing from the publisher. The CCC fee code is $0277-$ $786 \times / 19 / \$ 18.00$.

Printed in the United States of America by Curran Associates, Inc., under license from SPIE.

Publication of record for individual papers is online in the SPIE Digital Library.

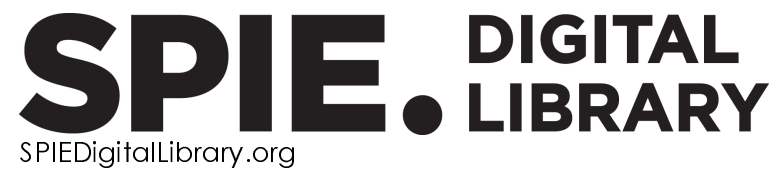

Paper Numbering: Proceedings of SPIE follow an e-First publication model. A unique citation identifier (CID) number is assigned to each article at the time of publication. Utilization of CIDs allows articles to be fully citable as soon as they are published online, and connects the same identifier to all online and print versions of the publication. SPIE uses a seven-digit CID article numbering system structured as follows:

- The first five digits correspond to the SPIE volume number.

- The last two digits indicate publication order within the volume using a Base 36 numbering system employing both numerals and letters. These two-number sets start with $00,01,02,03,04$, 05, 06, 07, 08, 09, OA, OB ... 0Z, followed by 10-1Z, 20-2Z, etc. The CID Number appears on each page of the manuscript. 


\title{
Contents
}

\author{
vii Authors \\ ix Conference Committee \\ xi Introduction
}

ADVANCED ALGORITHMS IN ATR I

$1098804 \quad$ HySARNet: a hybrid machine learning approach to synthetic aperture radar automatic target recognition [10988-7]

1098805 Shape-based ATR for wide-area processing of satellite imagery (Invited Paper) [10988-8]

1098806 Discrimination of forests and man-made targets in SAR images based on spectrum analysis [10988-9]

\section{ADVANCES IN MACHINE LEARNING FOR ATR I}

$1098807 \quad$ Explainable automatic target recognition (XATR) [10988-2]

1098808 A comparison of target detection algorithms using DSIAC ATR algorithm development data set [10988-3]

1098809 Fundamentals of target classification using deep learning (Best Student Paper Award) [10988-4]

10988 OA Simple linear regression model based data clustering [10988-5]

\section{ADVANCED ALGORITHMS IN ATR II}

$109880 \mathrm{C}$ Fast and robust detection of oil palm trees using high-resolution remote sensing images [10988-11]

10988 OD Semantic segmentation based large-scale oil palm plantation detection using high-resolution satellite images [10988-12] 
ADVANCED ALGORITHMS IN ATR III

10988 OF Design of adversarial targets: fooling deep ATR systems [10988-15]

$109880 G \quad$ Comparing classifiers that exploit random subspaces [10988-26]

$10988 \mathrm{OH} \quad$ Radar target recognition using wavelet-based features extracted from compressively sensed signatures [10988-27]

\section{ADVANCES IN MACHINE LEARNING FOR ATR II}

10988 OK On generalization of deep learning recognizers in overhead imagery (Invited Paper) [10988-18]

$10988 \mathrm{OL} \quad$ Automatic machine learning for target recognition [10988-19]

10988 OM Multisource deep learning for situation awareness [10988-20]

10988 ON Characterization of CNN classifier performance with respect to variation in optical contrast, using synthetic electro-optical data [10988-21]

\section{ADVANCED ALGORITHMS IN ATR IV}

$1098800 \quad$ Fast and accurate target detection in overhead imagery using double convolution neural networks (Invited Paper) [10988-22]

10988 OP Neural network classification of degraded imagery using soft labels: towards human-level performance with "accurate" likelihoods? [10988-23]

$109880 Q \quad$ Manifestly positive series approximation to probability densities [10988-24]

10988 OR Physically realizable adversarial examples for convolutional object detection algorithms [10988-25]

\section{ADVANCED ALGORITHMS IN REMOTE SENSING I}

10988 OT Transfer learning for aided target recognition: comparing deep learning to other machine learning approaches [10988-29]

10988 OV Deep learning based super resolution of aerial and satellite imagery [10988-43]

10988 oY Generalization ability of region proposal networks for multispectral person detection (Best Paper Award) [10988-33] 
$109880 Z$ Modeling the performance of modern sensor systems (Invited Paper) [10988-41]

ADVANCED ALGORITHMS IN REMOTE SENSING II

1098811 Cross-spectral face recognition with image quality disparity using image fusion [10988-35]

$1098813 \quad$ Nighttime periocular recognition at long standoffs with deep learned features [10988-37]

1098814 The development of synthetic thermal image generation tools and training data at FLIR [10988-38]

1098815 Real-time beacon identification using linear and kernel (non-linear) Support Vector Machine, Multiple Kernel Learning (MKL), and Light Detection and Ranging (LIDAR) 3D data [10988-39]

1098816 iECO learned matched filters for automatic target recognition in synthetic midwave infrared imagery [10988-40]

1098817 Research on image processing and intelligent recognition of space debris [10988-42] 
Proc. of SPIE Vol. 10988 1098801-6

Downloaded From: https://www.spiedigitallibrary.org/conference-proceedings-of-spie on 26 Apr 2023 Terms of Use: https://www.spiedigitallibrary.org/terms-of-use 


\section{Authors}

Numbers in the index correspond to the last two digits of the seven-digit citation identifier (CID) article numbering system used in Proceedings of SPIE. The first five digits reflect the volume number. Base 36 numbering is employed for the last two digits and indicates the order of articles within the volume. Numbers start with 00, 01, 02, 03, 04, 05, 06, 07, 08, 09, OA, 0B...0Z, followed by 10-1Z, 20-2Z, etc.

Aved, Alex, OM

Baker, Hyatt B., $0 Z$

Ball, John E., 15

Blasch, Erik, OL, OM

Cagle, Lucas, 15

Cao, Zhicheng, 11, 13, 17

Chambers, David R., OR

Chan, Moses W., 07

Cohen, L., OQ

DelMarco, Stephen, 05

Desai, Sundip R., 07

Diehl, Ashley, 0T

Dong, Runmin, OC, OD

Duffy, Jeffrey P., $0 Z$

Fay, David, 05

Fritz, Kevin, OY

Fu, Haohuan, OC, OD

Gantert, Jamie, OG

Garcia, Jordan, 0 Z

Garza, H. Abe, OR

Goley, G. Steven, OK

Gong, Cheng, 17

Gray, David, 0G

Guo, Linghua, 17

Hammoud, Riad I., 00

Hulsey, Don, 0G

Jarvis, Christopher, 05

Jones, Wesley A., $\mathrm{OZ}$

Jouny, Ismail, $\mathrm{OH}$

Kangas, Scott, OK

Klauck, Ulrich, OY

König, Daniel, OY

Konz, Latisha R., 04

Leong, Colin, ON

Li, Bingcheng, OA

Li, Weijia, OC, OD

Li, Weike, 06

Liu, Zheng, OM

MacDonald, Douglas N., 04

Madineni, Kedar, 14

Mahalanobis, Abhijit, 08, 09

Majumder, Uttam K., OL, OM

McIntosh, Bruce, 08

Mehmood, Asif, OV

Menart, Christopher, ON

Mendoza-Schrock, Olga, ON, OT

Nasrabadi, Nasser M., OF

Nguyen, Nhat X., 07

Nolan, Adam R., OK
Osahor, Uche M., OF

Osborne, Brayden, OK

Overman, Timothy L., 04

Pang, Liaojun, 11, 13

Philson, Jeffery R., OP

Price, Stanton R., 16

Price, Steven R., 16

Reisman, Matthew, 04

Reza, Tasmia, 15

Rice, Andrew C., $0 Z$

Rivera, Samuel, OT

Ross, Timothy D., $0 Z$

Rouse, Roger, 04

Rovito, Todd, OL

Snyder, William, 05

Soldin, Ryan J., 04

Song, Bin, 17

Stout, Arthur, 14

Tane, Zachary, 14

Tanner, Irene L., 09

Teutsch, Michael, OY

Thomas, Richard J., $\mathrm{OZ}$

Tom, Victor, 05

Tong, Shoufeng, 17

Tremblay, Lovis, 14

Velten, Vincent J., OL

Waagen, Donald, OG

Webb, Helen, 05

Wei, Pan, 15

Xia, Maocai, OC, OD

Xin, $Y u, 06$

$X u, X u a n, 11,13,17$

Yu, Le, OC, OD

Zelnio, Edmund, ON

Zhai, Hua, 17

Zhang, Bing cai, 00

Zhang, Haopeng, 17

Zhang, Lamei, 06

Zhao, Heng, 11, 13

Zhao, Weiqiang, 13

Zhao, Yuanming, 11, 13

Zheng, Juepeng, OC, OD

Zheng, Yufeng, $0 \mathrm{M}$

Zou, Bin, 06

Zulch, Peter, OL, OM 
Proc. of SPIE Vol. 10988 1098801-8

Downloaded From: https://www.spiedigitallibrary.org/conference-proceedings-of-spie on 26 Apr 2023 Terms of Use: https://www.spiedigitallibrary.org/terms-of-use 


\title{
Conference Committee
}

\author{
Symposium Chairs
}

Jay Kumler, JENOPTIK Optical Systems, LLC (United States)

Ruth Moser, Air Force Research Laboratory (United States)

Symposium Co-chairs

John Pellegrino, Electro-Optical Systems Laboratory, Georgia Institute of Technology (United States)

\section{Conference Chairs}

Riad I. Hammoud, BAE Systems (United States)

Timothy L. Overman, Lockheed Martin Space Systems Company (United States)

\section{Conference Program Committee}

Leon Cohen, Hunter College (United States)

Frederick D. Garber, Wright State University (United States)

Izidor Gertner, The City College of New York (United States)

Behzad Kamgar-Parsi, U.S. Naval Research Laboratory (United States)

Bing Li, Lockheed Martin Rotary and Mission Systems (United States)

Abhijit Mahalanobis, University of Central Florida (United States)

Olga Mendoza-Schrock, U.S. Air Force (United States)

Robert R. Muise, Lockheed Martin Missiles and Fire Control (United States)

Nasser M. Nasrabadi, West Virginia University (United States)

Vahid R. Riasati, California State University, Northridge (United States)

Firooz A. Sadjadi, Lockheed Martin Corporation (United States)

Angel D. Sappa, Escuela Superior Politécnica del Litoral (Ecuador) and Centre de Visió per Computador (Spain)

Jason R. Stack, Office of Naval Research (United States)

Alan J. Van Nevel, Naval Air Warfare Center Aircraft Division (United States)

Vincent J. Velten, Air Force Research Laboratory (United States)

Edmund Zelnio, Air Force Research Laboratory (United States)

Session Chairs

1 Keynote Session I

Riad I. Hammoud, BAE Systems (United States)

Timothy L. Overman, Lockheed Martin Space Systems Company (United States) 
2 Advanced Algorithms in ATR I

Abhijit Mahalanobis, University of Central Florida (United States)

3 Advances in Machine Learning for ATR I

Bingcai Zhang, BAE Systems (United States)

4 Advanced Algorithms in ATR II

Leon Cohen, Hunter College (United States)

5 Keynote Session II

Riad I. Hammoud, BAE Systems (United States)

Timothy L. Overman, Lockheed Martin Space Systems Company (United States)

6 Advanced Algorithms in ATR III

Vincent J. Velten, Air Force Research Laboratory (United States)

7 Advances in Machine Learning for ATR ॥

Vahid R. Riasati, Northrop Grumman Aerospace Systems (United States)

8 Advanced Algorithms in ATR IV

Bing Li, Lockheed Martin Rotary and Mission Systems (United States)

9 Keynote Session III

Riad I. Hammoud, BAE Systems (United States)

Timothy L. Overman, Lockheed Martin Space Systems Company (United States)

10 Advanced Algorithms in Remote Sensing I

Timothy L. Overman, Lockheed Martin Space Systems Company (United States)

11 Keynote Session IV

Michael Teutsch, HENSOLDT Optronics GmbH (Germany)

12 Advanced Algorithms in Remote Sensing II

Michael Teutsch, HENSOLDT Optronics GmbH (Germany) 


\section{Introduction}

Welcome to SPIE's Automatic Target Recognition Conference XXIX. This year had changes in chairmanship with Abhijit Mahalanobis and Firooz A. Sadjadi, two icons in the ATR community, stepping down to pursue other activities; and the introduction of two new ATR Conference Chairs Riad I. Hammoud and Timothy L. Overman. Abhijit and Firooz, thank you for your many years of service as Conference Chairs for the ATR Conference.

This year, as the new Conference Chairs, we spiced up the conference program a bit by adding new sessions in Machine Learning for ATR and Remote Sensing into our successful Machine Learning for ATR panel which we introduced last year. We also invited noted leaders and motivators in the community as Keynote Speakers to set the tone for each conference day. We also included more Invited Papers focusing on Machine Learning advancements in ATR.

This year we had a significant increase of published papers in these proceedings. We also brought back our Best Paper Award and Best Student Paper Awards this year. Our Best Paper Award went to Dr. Michael Teutsch for his paper on "ability of region proposal networks for multispectral person detection." Our Best Student Paper Award went to Ms. Irene L. Tanner for her paper on "Fundamentals of target classification using deep learning." Rumor has it, Ms. Tanner received five verbal job offers immediately after her presentation. The authors each received $\$ 2,500$ cash along with a nice award certificate from SPIE. Congratulations to the winners on behalf of SPIE and the ATR Conference Chairs and committee members. Our special thanks to the award sponsor Lockheed Martin Corporation for making this cash award possible. We offer these cash awards based on submitted paper quality and presentation effectivity at the conference, to encourage novel paper submissions from both students and the professional community.

We would like to thank the ML4ATR panel members Todd Rovito (Air Force Research Laboratory), Wesam Adel Sakla, (Lawrence Livermore National Laboratory), Erik P. Blasch (Air Force Research Laboratory), and Bingcai Zhang (BAE Systems). We would also like to thank Keynote Speakers Kevin Priddy (Air Force Research Laboratory), Richard W. Linderman (United States Office of the Undersecretary of Defense) and John Haddon (Lockheed Martin Corporation) for providing thoughtprovoking and exciting talks in Machine Learning and its impacts on ATR in all topics.

A special thanks to all the paper presenters and those presenters that were able to fill in for scheduled presentations. A very special thanks to the SPIE staff for their support in organizing a very successful conference in 2019. Finally, a special thanks 
to the attendees who provided an audience and engaged with the presenters, without you this conference would not be possible.

We are planning a book project on ATR which will provide an up-to-date comprehensive review of the ATR field leveraging selected papers from the ATR conference proceedings. Finally, we look forward to your participation next year at the ATR Conference XXX for SPIE Defense + Commercial Sensing 2020, April 2630 , in Anaheim California.

Riad I. Hammoud Timothy L. Overman 